\title{
Critical Review: Professional Development Skill for Operational Excellence in Context to Financial Sector
}

\author{
Trilok Singh Randhawa, Dr. Sapna Singh \\ Research Scholar, Department of Management, SRK University of Bhopal, India \\ Department of Management, SRK University of Bhopal, India
}

\begin{abstract}
The researcher stated a significant approach of critical review with respect to professional development skill for operational excellence in context to financial sector, to sustain in the market and grow it has been become necessary for the Financial sector organisations to achieve Operational Excellence, which leads to Higher customer satisfaction, Lower operational costs, Increased shareholder value, Economies of scale etc. which leads to a more sustainable organization. This requires a skilled and upgraded employee. Many companies in India other than multi-nationals are not meeting the employee demands with reference to training and development and ultimately the gap is found in the required skills for achieving Operational Excellence vis-a-vis attained skills. Training needs Analysis is an organizational approach to analyse and asses that is derived from the foundation containing gap analysis. The analysis and assessment of the difference between the skillset, knowledge, habits and attitudes that needs to be attained by the organisational employee to achieve organisational objectives of profitability, knowledge, productivity and skillset that the current employees in the organisation possess. In this research article the researcher represented a critical review of professional development skill for operational excellence in context to financial sector.
\end{abstract}

Keywords : Professional Development Skills, Operational excellence, Financial Sectors.

\section{INTRODUCTION}

The financial system is a backbone of the nation's economy and plays a very vital role in the growth of its economy serving all the sectors financially. As it affects all the sectors of a. A sound and fair financial environment are mandatory for the growth and success of business and industry of an economy. Finance bridges the gap between present and future. The financial system is a set of complex and closely related institutions that mobilise savings from the savers and transforms them into investments. A sound financial system is an important element to achieve national objectives.
The financial system is the well-knit structure of integrated, organised and regulated financial institutions, financial markets, financial instruments, financial services, practices and procedures. Financial system fulfils the short term and long term needs of the household sector as well as the corporate sector. It provides a mechanism that mobilises surplus funds from the savers and allocates them in productive activities. The financial system deals with all types of finance- agriculture, industrial and finance for the government sector. It is concerned with borrowing and lending of funds of all the individuals, institutions, companies and the government. It provides all the relevant information to all the players of the market. The government of India has been taking several regulatory measures to improve 
the financial system in the country and to ensure operational autonomy.

A financial system handles the demand for supply of financial funds, commonly identified as loans, savings, investments etc. for the individual as well as business needs.

Financial markets are a term commonly used to refer money markets that facilitate borrowing and lending process. It's a market place which allows people to get involved in investing, trading securities, bonds, stocks, commodities like metals, livestock's, food grains etc. via various services provided in the financial markets by the players.

1. Financial markets are made up of the following. Capital Market - which acts as a primary and important market?

2. Money Market- Foreign Exchange Market: RBI and registered dealers are part of it along with exchanges, foreign banks, importers and exporters who are in need of these services.

3. Government Securities: Bonds, bill and other government instruments.

Financial institutions act like a backbone or most important $\operatorname{cog}$ in the Indian financial industry as it acts brokers managing the activities and balancing the funds between the borrowers with needs and the lenders. It helps in channelling excess or superfluous funds via different financial instruments within the market players.

These financial institutions facilitate funds transfers among different kinds of banking and allied companies, many times taking up the advisory roles and acting on their behalf to deal with important banking players like RBI, Cooperative banks, Commercial banks, Development Banks, Agriculture Banks, Merchant Banks and more what forms the structure of the banking institution.
Apart from these developmental banks, there are other banks that are enjoying an important place in fortifying the Indian banking and financial systems, they are named the agriculture banks, the merchant's banks and the likes. The number of NBFCs operating in India is quite large consisting of various institutions like the Chit Funds, Mutual Funds, Factoring Companies and the likes. These are primarily privately owned organisations that are involved in activities facilitating deposit acceptance and loan dispersal. The act on a higher margin of work which consists of high-interest rates on the loans provided but also takes the risk of providing on cut security. RBI sees over these organization and their activities and regulate them.

Financial instruments are a sort of token in a real or virtual format. These are essentially contracts in documentation between two players involved in the activity or business without any physical asset involved. Bonds, debentures, equity, stocks, derivatives market instruments etc. are the instruments available in the Indian financial market. These are the services provided, promoted to the customers by the financial institutions within the financial markets on their products like Mutual Funds, Venture Capital Funds, credit rating, Leasing and the likes.

\section{Non-banking Financial companies (NBFCs):}

Non-bnking Financial companies (NBFCs) are quite important in the Indian Financial system. It's acting as a conduit allowing an increased fund flow in the commercial sector on the Indian industry. NBFC also is useful in providing an added support required by the Indian finance institutions to cope up with the corporate demands. NBFCs, that are private in nature are institutions that are quite specific in providing financial services and cover various 
instruments and products including assets in physical form, commercial loans involving vehicles, loan on infrastructure and the likes. RBI regulates NBFCs that are in these financial activities involving lending, deposits, and investments etc. There are few exceptions i.e. the NBFI activity NBFCs like housing finance companies (HFCs), mutual funds brokers, insurance companies, stock broking firms, merchant banking and venture capital funds (VCFs), when such institutions are governed by other regulatory bodies.

Types of NBFCs: The classification of the NBFCs are unique to their purpose and is done on the criteria of their working, that be the structure of their liabilities, the activities and initiatives undertaken by them and the importance within the system.

Below are the NBFCs with their specifics.

\section{LITERATURE REVIEW}

Types of NBFCs: The classification of the NBFCs are unique to their purpose and is done on the criteria of their working, that be the structure of their liabilities, the activities and initiatives undertaken by them and the importance within the system.

Below are the NBFCs with their specifics.

1] Asset Finance Company (AFC). 2] Loan Company (LC). 3] Investment Company (IC). 4] Core Investment Company (CIC). 5]. Factoring -NBFC. 6] Infrastructure Debt Fund Non-Banking Financial Company (IDF -NBFC). 7] Infrastructure Finance Company (IFC). 8] Non-Banking Financial CompanyMicro Finance Institutions (NBFC-MFIs). 9] NonOperative Financial Holding Company (NOFHC). 10] Mortgage Guarantee Companies (MGC). 11] NBFCAccount Aggregator (AA).(Goyal. S, 2015) [18]

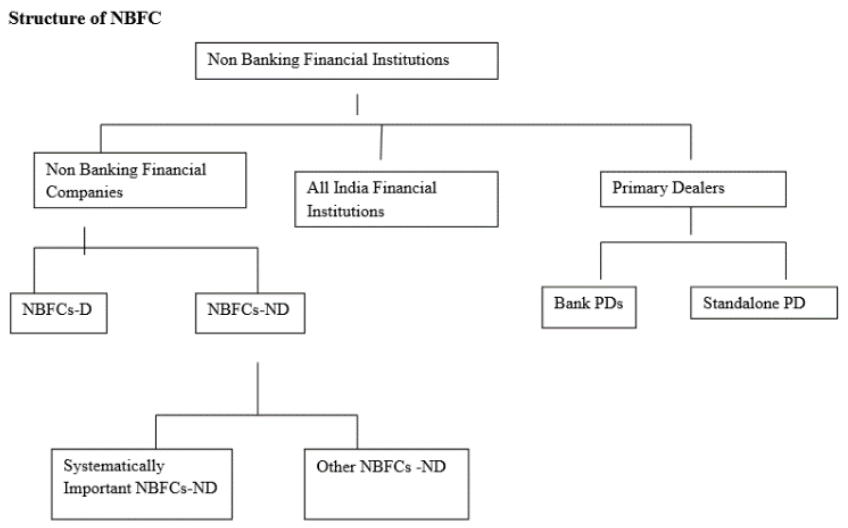

Fig1.1: Source:

https://www.rbi.org.in/Scripts/FAQView.aspx?Id=92. (Kaur D, 2018)[17]

The following table shows the various financial indicators from the financial year 2013-14 to financial year 2016-17 (RBI, 2017) [15]

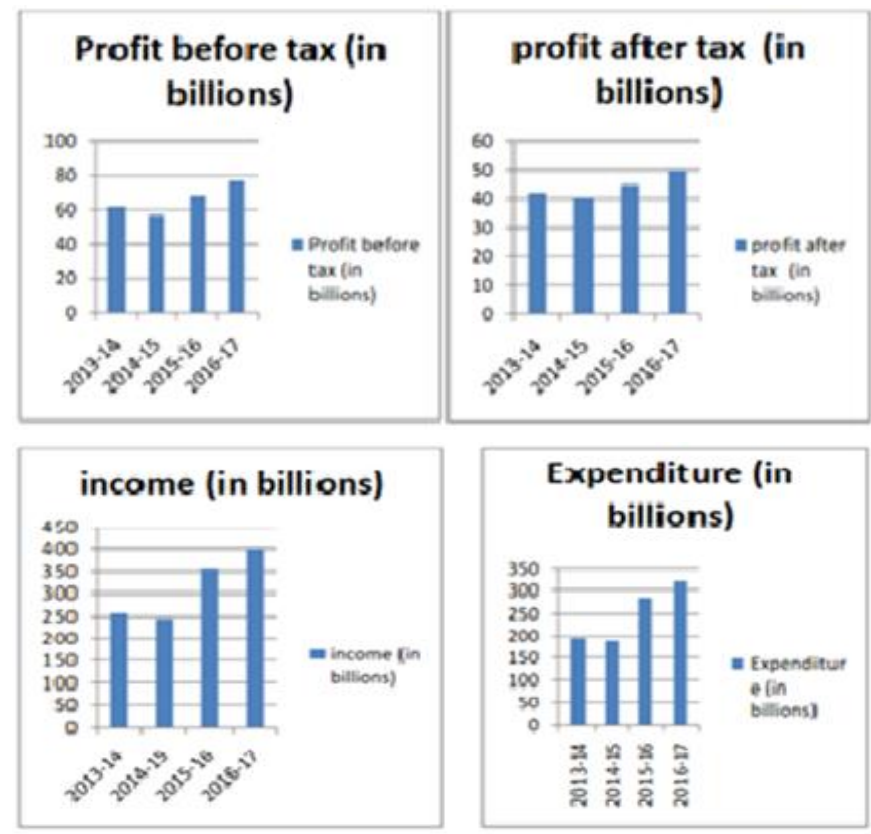

Fig1.2: Source: RBI database on Indian economy

IMF chief Christine Lagarde (May 6, 2015) Nearly two billion people globally do not have bank accounts including those in the US ruing that financial systems around the world despite being sizable exclude many individuals from financial services. (Mohan. R, Ray. P, 2016)[16] 
The changes are observed are more in the countries like India that are in the developing stage, that depends on the investments like foreign direct investments, expansion of trade, outsourcing, that would benefit and develop the economy. Thus the main driving force of economy is the skillsets and tech know-how of the workforce that lead to social development of any nation as such. Economics having these assets could react more efficiently to absorb opportunities and face the challenges. GOI defines Skill as the "set of competencies essential to carry out the required tasks in the most efficient way while maintaining the agreed set of quality standards". A process to enable the workforce with the required skills and imparting relative knowledge though various training and development programmes to satisfy the current industry needs to stay continuously competitive in this fiercely every demanding dynamic international market (Maclean, 2013) [4].

Indian industry sector noted the importance of corporate training has been realized by the rapidly changing technology scenario over time. As companies are going ambitious, setting up branches and offshore offices all over the world this forming a multinational organization, the need for a welltrained performance-oriented workforce is imperative though not necessarily available. Hence companies are zooming out from the skewed opinion about their employee and beginning to develop them making them as an asset for themselves thus contributing their profits by retaining them. The capital spent in these training and development activities can be off-settled by the development of a well-trained workforce, unique to their process performing on higher level resulting in profits more so acquiring higher retention, instead of spending on staffing activities. Training has been absorbed in each sector from sales, marketing, manufacturing, production, logistics, human resource functions, engineering to inventory management etc. Indian firms have concentrated on the on-job training and other organization based training courses that are designed to lead a fast track development of new inductees more so on the technologically advanced industry to fulfil the requirement for skilled human resource. The corporate training market has seen an exponential increase in the information technology sector with growth to INR 210 crore from INR 600 crore according to NASSCOM. [Chetty. P, 2011)[11]

1.2 Operational Excellence and need of Operational excellence in general and in Finance sector.

Excellence a word that's generally in use to denote or mention something that's quite high in regards w.r.t skills, performance or management wise with respect to any individual or organization (Opex MIT, 2018)[2]. In an organization, the term could mean the reputation of the organization and also elements of its working be it employees, management, product and services on offer by that entity that are seen quite promising and commanding trust. It is also used to specify the performance of the organization. The difficulty in defining organizational excellence is due to its intangible elements that difficult to measure or quantify. Excellence is an attribute that can be only observed in terms and against the competition.

\section{Operational excellence timeframe}

Different meanings through the years

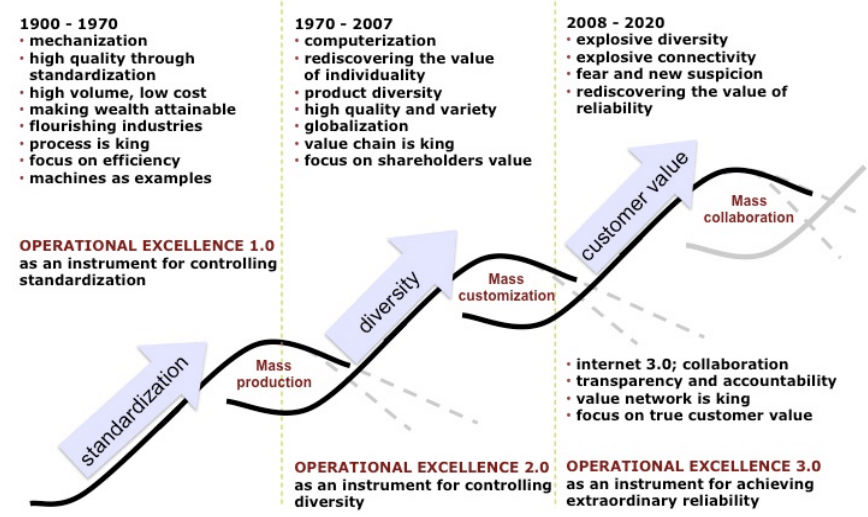

Fig.1.3: Operational Excellence Framework 
The operational excellence evolution is described in the following and is categorized is into three time frames as shown in the above figure.

Competition is a core value that evolution itself is based on. As seen in the animal kingdom it has realized into fights between different species, interspecies, genders for domination as well as for procreation. This can be transferred to the current organizational ecosystem. There is always a sense of competitions among organizations in the business world. The prize here is customer base, confidence, investors etc. Operations excellence allows these organizations to have a say, to lead in achieving this objective with a display of greater efficiency. A philosophy comprising of leadership, organizational teamwork, problem-solving allowing a continuous development throughout all the sectors within an organization with a focus on the customer problems, their needs, a process to empower their human resource, and increasing the efficiency of their existing organizational programs in the process in operational excellence.

The business excellence models that are widely recognized are the Deming Prize, the Australian Business Excellence Framework, the Baldrige Performance Excellence Framework, the European Framework for Quality Management Excellence Model, the Canadian Framework for Business Excellence, the Singapore Business Excellence Model and the Kanji's Business Excellence Model, Kaizen. (Dodangeh et al., 2012)[9].

Operational excellence since inception has been an important tool to gain competitiveness in various sectors of the firm from production to service. An organisation, therefore, should have its operational strategy well versed and checked before the application of operation strategy decisions on operational excellence given its high impact. There are various factors that can be part of the process to achieve operational excellence that includes management roles and practices, operational strategies, human resource; leadership is prime and also the culture of involvement and inclusiveness.

\section{PROBLEM STATEMENT}

India as a country has seen a tremendous growth in the financial sector in the last decade. But it is essential for the organisations in the sector to achieve Operational Excellence to sustain in the dynamic sector. Financial sector being the service sector, It requires the employees of the organisations to be sufficiently skilled and upgraded. It has been seen that there is a huge gap between the skills required by the employees and skills attained by the employees. To bridge this gap, organisations take help of Professional development programs like training and development, Certification programs, Seminars workshops, higher education studies and so on. This has been done without checking the efficiency of the program chosen for the employees of the Finance sector. The Professional Development Programs when arranged do not have the same parameters behind its selection than the need identification and effectiveness of the Professional Development Program.

\section{RESEARCH OBJECTIVES}

The researcher stated that the effective methods of Professional development amongst the Financial sector employees, which results in Operational excellence and ultimately not only survival but also growth of the organisations in the financial sector. The researcher stated some of the research objectives which are given below: 
Research Objectives:

1. To understand Professional Development skills required for Operational excellence in Financial Sector.

2. To study various training methods used for Professional Development in the Financial Sector.

3. To analyse the use and effectiveness of these training methods.

\section{RESEARCH DESIGN AND METHODOLOGY}

Research plan is a systematic investigation to find answers to a problem. Research in the professional social science areas, like in other subjects, has generally followed the traditional objective scientific method. Since the 1960s, however, a strong move towards a more qualitative, naturalistic and subjective approach has left social science research divided between two competing methods: The scientific empirical tradition, and the naturalistic phenomenological mode which are adapted for selecting the sample, data collection method, and statistical method, finally to generate the inferences to achieve the objective of the research work on exploration of information technology and its advances in methodology of Professional Development Skill i.e. Trainings with respect to Achieving Operational Excellence that were derived from literature and meant to answer the research question which is to investigate, what extend towards the research study.

The researcher designed the framework of research study and established the correlation between dependent and independent variables, on the basis of that researcher identified the variables and affecting factors in Role of Professional Development Skill for Operational Excellence In context to Financial Sector In Bhopal \& Indore Region and developed the questionnaire for data collection. Questionnaire is the structured approach of primary data collection, which was collected from the different rural areas financial banking sectors.

\section{ANALYSIS AND DISCUSSION}

Understand Professional Development skills required for Operational excellence in the Financial Sector. Dearth of training and development leading to wider requirement and demand gap. The skills attained during the regular institutional education are finding less space in the application in the corporate and industrial sectors. Operational excellence consists of a system, management specific that is spread and interlinked across various functional units providing a synergy aiming towards a continual increase in operational and organisational performance.

Training in developmental activities in an organisation is the process that's prime to achieve operational excellence. HRD functions as a tool in understanding skillset required for achieving operational excellence. The skillset, quality of the staff in organizations can improve and also be enhanced by induction of education and promotion of inclusiveness using operational excellence. Training methodologies used for Professional Development in the Financial Sector.

Observations and interpretations highlighting the methods involved in training like in the job training methods. Management and employee training module. Importance of imbibing innovation and technology know-how in the workforce via programs such as vocational training modules, designed by higher education institutions.

Training modules benefits in improving organisational and inter-organisation communication. Engaging and simpler ideas of training and 
development. Corporate training and development policies and practices. Differences between Training and Development. Human resource functions as a methodology: Discussion on the effectiveness of training and development initiatives on the objectives set for its employee and also for the organizations.

Measure of effectiveness of training. Effect of failure in the effectiveness. Canara Bank study on the training and development measures. Effects of strategic human resource development as a factor in the evaluation process of the effectiveness. HRM use by different organisations in a customised manner to achieve their specific goals.

\section{VII.CONCLUSION}

In this research paper the researcher emphasized that a significant approach of importance of the trained and skilful employee for achieving Operational Excellence in Financial Sector. The studies show that most of the financial sector organisations being medium to large scale organisations are arranging various Professional development programs like Training \& Development, certification programs, Higher education opportunities for skill enhancement of their employees. But very few studies have been done which try to find out the impact of these Professional development programs arranged by organisations on their employees with respect to achieving Operational Excellence.

The Professional Development Programs when arranged do not have the same parameters behind its selection than the need identification and effectiveness of the Professional Development Program. A study is required to analyse the use and effectiveness of these Professional development Programs in achieving operational Excellence. Further to understand technology based training methods and higher education and its impact on operational excellence on existing employees on operational excellence and to find out the best suitable methods in Financial Sector for achieving Operational Excellence.

\section{REFERENCES}

[1]. Shehadeh R, Maqableh M, Orsan Al-Zoubi, Abdel hakim. M, Majed Khalil Al-Sham A. (2016) Review the Operational Excellence Factors of Service Firms.

[2]. Operational and Organizational Excellence September, (2018) MIT Gurgaon.

[3]. Vinesh, 2014, Role of Training \& Development in an Organizational Development.

[4]. Janice A. Miller, SPHR and Diana M. Osinski SPHR (2002), Training Needs Assessment, February 1996 Reviewed July 2002.

[5]. Sakshi Sethi, Dr Esha-Sharma, (2015) SkillDevelopment Opportunities Challenges in India.

[6]. https://tallyfy.com/guides/operationalexcellence/\#What_is_Operational_Excellence

[7]. Ashish Dikshit1 Trilok Kumar Jain (2017), Training and Skill Development for Employee Retention and Performance Enhancement in Banks.

[8]. Ravi, V., (2001), Model of a Quality System for Training Development in Organizations, Indian Journal of Training and Development.

[9]. Dodangeh, J., Rosnah, M. Ismail. Y.Y Biekzadah, M.R, \& Jassbi, J. (2012) A review on major business excellence frameworks. Technics Technologies Education Management, 7(3).

[10]. Dr.Aliya Sultana, P.Naganandini Devi and Navyateja (2014) Training and Development Issues in the Indian. 
[11]. Priya Chetty (2011) Training and Development Scenario in India.

[12]. Jadhav Ajit (2013), “A Study on Training and Development in Indian Banks.

[13]. Andrew Miller, 2014 Redefining Operational Excellence: New Strategies for Maximizing Performance and Profits across the Organization.

[14]. Nitin Kirnapure (2011): Present trends of financial sector in India, slideshare.net, Jan'2011.

[15]. RBI (2017): Present banking and non-banking scenario in India, 07 Apr 2017, Point no. 2.2.2.

[16]. Rakesh Mohan, Partha Ray, (2016,) Indian Financial Sector: Structure, Trends, and Turns, Stanford Centre for International development.

[17]. Davinder Kaur, (2018) A STUDY OF FINANCIAL PERFORMANCE OFNBFCs, International Journal of Management, IT \& EngineeringVol. 8 Issue 10.

[18]. Shilpa Goyal, (2015), Indian Financial System. Int J Recent Sci Res, 6(9).

[19]. Shanmuganandavadivel J, Dev D, (2018) PERFORMANCE OF NBFCS -AN INDIAN CONTEXT, International Journal of Pure and Applied Mathematics, V 119,

\section{AUTHORS DETAIL}

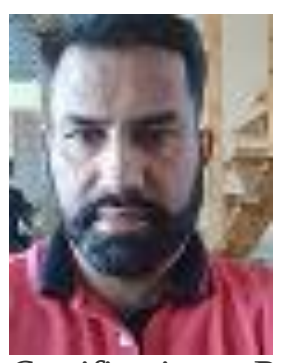

\section{Trilok Singh Randhawa}

dynamic professional with over 18 Years of Experience

in various domains including Finance, Banking, Taxation, Stocks, MF, Info Security, Education, IT Certification, Process Consulting and eLearning. With an M.COM in Taxation, MA-Economics, MBA in Marketing and IT, Executive MBA in Project Management under his belt, Trilok has served as a career coach and mentor to several successful IT professionals over the years. Trilok, who is also the Chief Information Officer at Zoc Technologies believes in offering solutions to existing career challenges through mentoring and career guidance and all of its beneficiaries have vouched for the same consistently.

Dr. Sapna Singh has completed Ph.D. in Business Administration and Management from University of Lucknow, Lucknow and Post graduation in MBA from IMS, University of Lucknow, Lucknow. Dr. Singh completed her BBA from Ghaziabad. She has teaching experience of 11 yrs and research 5 yrs. She has published various research papers in impact factor journals national \& international repute. She has attained various National and International conferences, FDP and MDP. Presently Dr. Singh is working as Associate Professor in Department of Management, SRK University, Bhopal. Dr. Singh supervised and supervising more than $20 \mathrm{MBA} / \mathrm{BBA}$ projects and $6 \mathrm{Ph} . \mathrm{D}$. research scholars.

\section{Cite this article as :}

Trilok Singh Randhawa, Dr. Sapna Singh, "Critical Review: Professional Development Skill for Operational Excellence in Context to Financial Sector ", International Journal of Scientific Research in Science and Technology (IJSRST), Online ISSN : 2395-602X, Print ISSN : 2395-6011, Volume 6 Issue 4, pp. 13-20, July-August 2019. Available at doi : https://doi.org/10.32628/IJSRST196331 Journal URL : http://ijsrst.com/IJSRST196331 